\title{
Conjoint analysis to understand preferences of contraceptives among women of reproductive age in Ukraine
}

\author{
Tamara Mahanova ${ }^{1}$, Natalia Tkachenko ${ }^{1}$ \\ 1 Zaporizhzhia state medical university, Zaporizhzhia, Ukraine \\ Corresponding author: Tamara Mahanova (bataneofarm@gmail.com)
}

Received 5 January 2021 • Accepted 27 January 2021 • Published 1 April 2021

Citation: Mahanova T, Tkachenko N (2021) Conjoint analysis to understand preferences of contraceptives among women of reproductive age in Ukraine. Pharmacia 68(2): 291-299. https://doi.org/10.3897/pharmacia.68.e62794

\begin{abstract}
This article describes the results of marketing research using conjoint analysis that was conducted to establish the preferences of contraceptives among women of reproductive age in Ukraine to further use the results for effective marketing decisions making in the pharmaceutical industry.

It was established that the women `s choice differs significantly depending on their main socioeconomic characteristics: age, income level, and level of education. Priority contraceptives from hormonal, non-hormonal contraceptives, as well as contraceptive medical devices for different age groups of women, was identified. Alfred Marshall's main economic law was confirmed and the existence of price elasticity according to preferences was established.

The results obtained on women's preferences for certain types of contraceptives will improve the level of compliance, women's pharmaceutical safety and promote a balance between women's needs and the capabilities of the contraception supply system.
\end{abstract}

\section{Keywords}

contraceptive, women's preferences, conjoint analysis

\section{Introduction}

Effective demographic policy, family planning, maternity protection and preservation of the woman's fertile function, some socioeconomic issues, the search and development of innovative contraceptives are related with the contraception supply system.

Today, the problems of optimizing and improving the provision of women of reproductive age with high-quality and effective contraceptives, as well as increasing the level of responsibility of women in planning pregnancy and the ethical choice of contraceptives still relevance.
Recently, various aspects in this direction are devoted different works on the choice of a long-term method of contraception (Gormley et al. 2019), the implementation of condom distribution programs in the United States (McCool-Myers 2019), the role of the drug store in family planning and possible programs in this direction (Chin-Quee et al. 2018), social marketing campaigns strengthening the promotion of condoms and other contraceptives to prevent pregnancy (Ali Mohamed and Cleland 2018), the economic benefits of contraceptives (Mavranezouli 2009).

Ukrainian scientists do not lag behind in this direction (Zaliska and Stasiv 2020). However, the improvement of 
the drug supply system, including the contraception supply system is a continuous process.

The modern pharmaceutical market works on the principles of patient-oriented, the consumer's right to choose, and the equality of all market participants. In addition, understanding the preferences of consumers and maximizing satisfaction is the way to the success of any pharmaceutical company.

The key elements in the consumption process remain utility, as the ability of a product to satisfy a need, and the consumer himself, who receives and processes information before making the choice of a pharmaceutical product or service. Robert Keith (1986) called this shift a "marketing revolution": "The customer, not the company, is at the center ... Companies revolve around the customer, not the other way around".

A woman as a consumer, who receives and processes information in the real conditions of the pharmaceutical environment, evaluates a number of characteristics of a contraceptive, its utility. She accordingly determines the price she is willing to pay and her preferences when making a purchase decision, based on the subjective utility of contraceptives.

This kind of valuable marketing information makes it possible to make high-quality management decisions at all levels of supply and allows correcting many of the processes taking place in these systems: from legislation to price regulation. Based on knowledge about the preferences and willingness to pay of the female consumer, this marketing information helps to create effective assistance programs at a time of money austerity. The main feature of these programs is taking into account the individual needs of consumers of different psycho-emotional, socioeconomic, and age status, and help to follow with the principle of compliance.

One of the main methods of obtaining this marketing information remains conjoint analysis. This is a multivariate research method that assesses women's contraceptives preferences by determining the value and the subjective utility of contraceptives and utility of their characteristics.

Conjoint analysis is used successfully to assess preferences in a variety of medical interventions (Arroyo et al. 2017; Stuart et al. 2018; Visser et al. 2020). The International Society is actively developing this research method for Pharmacoeconomics and Outcomes Research with the aim of further introducing it into the everyday pharmacoeconomic practice of pharmaceutical specialists (Bridges et al. 2011; Hauber et al. 2016).

Similar marketing research using conjoint analysis is regularly carried out in many countries and affects both certain, specific types of contraceptives (Jakimiuk et al. 2011; Higgins et al. 2015) in different periods of a woman's life (Bugaevskyi 2016; Norman et al. 2019). Besides, they explore certain links between the choice of contraceptive with the socioeconomic and cultural environment in which the woman lives (Janevic et al. 2012; Snopkowski et al. 2016; Alsaleem et al. 2018).

These data of the research allow smoothly adjusting to modern realities, optimizing and improving the operati- on of such supply systems to increase the efficiency of the functioning of both a separate contraception supply systems and the entire health care system as a whole.

The aim of the research was determining and analysis preferences of contraceptives among Ukrainian women of reproductive age, with the further use of the results obtained for effective marketing decisions making by pharmaceutical companies.

\section{Materials and methods}

\section{Design of sample}

The main research method was a regular conjoint analysis (RCA) in the form of a hall-test (https://dictionary. cambridge.org/dictionary/english/hall-test) for women of reproductive age (https://www.who.int/ru/news-room/ fact-sheets/detail/women-s-health; https://www.who.int/ publications/i/item/9789241549158; https://zakon.rada. gov.ua/rada/show/v0059282-14\#Text) of Zaporizhzhia region of Ukraine. A quota sample of 420 people was formed.

The size of the quota sample was determined by the requirements for the size of groups when conducting conjoint analysis (Kumar et al. 1995), as well as the assumptions of sociologists about the competitiveness of quota samples, which correspond to the size or exceed the size of the calculated random sample for the same general population $(\mathrm{N}=384369 ; \mathrm{n}=384 \pm 19 ; \alpha=0.05$ ) (Dobrenkov and Kravchenko 2007; Osipov 2009). The quotas were formed using data on education, per capita income, and age of women. There are the key socioeconomic characteristics that determine women's preferences of contraceptives (Alsaleem et al. 2018).

The representativeness of the sample was achieved due to the formation of quotas of such sizes that proportionally corresponded to the real allocation of women in the structure of the general population according to above-mentioned socioeconomic characteristics. The data for the formation of quotas were obtained from the State Statistics Service of Ukraine (http://www.ukrstat.gov.ua/). By age, seven quotas were formed: $16-19$ years old $(\mathrm{n}=29), 20$ 24 years old $(n=42), 25-29$ years old $(n=60), 30-34$ years old $(n=78), 35-39$ years $(n=73), 40-44$ years $(n=70)$, $45-49$ years $(n=68)$. The gradation of the age scale and division into quotas was due to the methodological foundations of conducting sociological surveys, WHO recommendations, as well as ethical and Ukrainian legal norms (the reproductive age of 15 years is excluded) (Myagkov 1996; https://zakon2.rada.gov.ua/laws/show/2341-14; https://ukraine.ureport.in/v2/opinion/652/).

Further, quotas were formed according to the level of per capita income: income up to 3,000 UAH (87 EUR) - $20.7 \%$ of the age quota; from 3000 to $4400 \mathrm{UAH}$ (87 EUR - 127 EUR) - 34.3\%; more than 4400 UAH (more than 127 EUR) $-45 \%$ of the age quota. This approach was based on the assumption of the obligatory existence of a middle class in any society, as well as on the assumption 
that a woman of any age may not work or her income is the total income of the whole family (Rachok at al. 2016).

Further, the formed quotas according to two characteristics (age and income) were divided based on the level of education: the quota of respondents with higher education/plan to get a higher education was $47.1 \%$, and the quota of respondents without higher education (school, college, technical school)/do not plan to get a higher education $-52.9 \%$.

\section{Design of experiment}

The women were gave three sets of cards with Contraceptive Profile (CP) in turn, as well as a preliminary introductory material on essential contraceptives. The main task of women was to rank cards with CP in decreasing order of their preferences from the most utility (attractive) CP to the least utility CP. It should be noted that the study took place with personal contact with the respondent during a casual conversation, which significantly increases the realism of the results.

\section{Attributes and levels}

Two independent variables were chose as the attributes (main characteristics) that were presented on the cards and forming the analyzed CP: contraceptive (image for visualization, level of protection, method of application) and price.

The list of studied contraceptive was formed based on WHO recommendations regarding medical criteria for the acceptability of contraceptive use, Ukrainian clinical guidelines for family planning, as well as was taken into account the attitude of contraceptive to groups of drugs containing hormones, non-hormonal drugs, and medical devices (https://www.who.int/publications/i/ item/9789241549158; https://zakon.rada.gov.ua/rada/ show/v0059282-14\#Text).

The first set of cards included hormonal contraceptives drugs: pills, injections, subcutaneous implant, skin patch, vaginal ring, and intrauterine therapeutic system. The second set of cards contained non-hormonal contraceptives drugs: vaginal suppositories, vaginal cream/ointment, vaginal aerosol, and a sponge with a contraceptive. The third set of cards included an intrauterine contraceptive (IUC) with silver/gold/copper, male and female condoms, as well as a cervical cap and a diaphragm.

Accordingly, in each set of cards, the contraceptive attribute had a different number of clearly identifiable, realistic levels: $1^{\text {st }}$ set -6 levels (hormonal drugs); $2^{\text {nd }}$ set -4 levels (non-hormonal drugs); $3^{\text {rd }}$ set -5 levels (medical devices). The number of levels of the price attribute was the same in each of the sets and amounted to 6 levels: 0\% of the maximum market price, $20 \%, 40 \%, 60 \%, 80 \%$, and $100 \%$, respectively.

Price values in the profiles were indicated in monetary terms to increase the visibility of the CP. This price division was due to the recommendations for conjoint analysis, and provided an opportunity for price modeling in programs for women and the pharmaceutical market of Ukraine (SPSS Inc.; Debashis Parti 2002; Orme 2007). As a result, three complete sets of profiles were obtained: $6 \times 6$ $=36 ; 4 \times 6=24 ; 5 \times 6=30$ that were used in the survey. We deliberately avoided the formation of an orthogonal plan with a decrease in the number of studied profiles, since this manipulation could reduce the quality of the resulting linear model.

\section{Statistical analysis}

The main calculations were performed in the SPSS 23 software environment (SPSS Inc., Chicago, IL, USA) and Excel 2010.

Relative preferences were obtained based on the ranks assigned by the respondents for three hypothetical scenarios for hormonal contraceptives, non-hormonal contraceptives, and medical devices. The ranks were in a hierarchical order, which indicated which cards were more or less preferred on an ordinal scale. The respondents' contraceptive preferences were collected for each respondent separately and for age quotas in general. To estimate the parameters, the usual regression model of ordinary least squares (OLS) was used.

The model estimated by the OLS method depending on attributes and levels is as follows:

$$
Y=a+\Sigma \beta i j \mathrm{x} i j+e
$$

where, $Y$ - is the utility for the analyzed CP; $\alpha$ - is constant or intercept term; $\beta i j$ - is the utility associated with the $i$-th attribute in the $j$-th level; $x i j=1-$ when the $j$-th level of the $i$-th attribute is present in the CP; $x i j=0$ - when the $j$-th level of the $i$-th attribute is absent in the CP; $e$ - is the standard error.

The CP card was the dependent variable, and the attributes used to generate the card profiles were the independent variables. The utility coverage (relative importance) for each attribute was calculated by dividing the difference between the minimum and maximum value of utility of an attribute in a group by the total of the utility of all attributes.

\section{Results and discussion}

The answers of all 420 respondents were valid and were included in the study; there were no inversions in all age groups.

First, the partial values of the levels of the attribute of contraceptives of all three hypothetical scenarios by age group were assessed, which showed significant differences in the preferences of women of different ages.

Pearson's R and Kendall's $\tau$, which measure the correlation between observed and evaluative preferences and are used to assess model fit, showed high correlation scores across all age groups for the three hypothetical scenarios. The calculated coefficients of the determination indicated 
a well-described linear model and the presence of a linear functional dependence $\mathrm{R}^{2}>0.95$.

Table 1 presents the $\beta$ utility coefficients of the levels of the hormonal contraceptive attribute. For the age group 16-19 years, the most preferable were the skin patch, intrauterine therapeutic system, and subcutaneous implant. In our opinion, it indicates the adherence of young women for methods of contraception that are more expensive but convenient and long-term using. In the age group 20-24, women preferred the tablet and injectable forms of contraceptives. The same result was obtained in the 25-29 age group.

It should be noted that in both groups the pills takes $1^{\text {st }}$ place in preference $(\beta=4.11 ; 3.89)$, which is due to the active prescription of this particular form of hormonal contraceptives among doctors, as well as the most common form on the Ukrainian market today (Mahanova and Tkachenko 2019a). In the age group 30-34 years, approximately the same preference was given by women to injectable, cutaneous and oral forms of hormonal contraceptives $(\beta=2.52 ; 2.15 ; 1.86)$, as well as a positive $\beta$ coefficient for the vaginal ring was established.

The highest values of the utility coefficients in the age group 35-39 years were found for oral, injectable and cutaneous forms of hormonal contraceptives. Moreover, value of the $\beta$ utility coefficient of hormonal pills was 2 times higher than the values of other drugs $(\beta=4.61)$. In the 40-44 age group, preferences corresponded to the 30-34 age group. For the 45-49-year-old group, the only attractive contraceptive methods were the skin patch and vaginal ring.

In all age groups, except for the 16-19 age group, the least attractive hormonal contraceptives with negative $\beta$ utility coefficients were a subcutaneous implant and an intrauterine therapeutic system. Such values of the utility coefficients are quite explainable by the relatively new form of production of an implantable hormonal contraceptive for the Ukrainian market, as well as by the high price for these hormonal drugs - $4175 \mathrm{UAH}$, and 2430 UAH (121 EUR and 70 EUR respectively).

Table 2 presents the $\beta$ utility coefficients of the levels of the non-hormonal contraceptive attribute levels that were included in the second scenario of the RCA study.

Note that the least attractive non-hormonal contraceptive in the opinion of women was a sponge with spermicide, in all age groups $\beta<0$. Such a consumer's reaction to the product is due to the lack of information in most women about this contraceptive, and associates with the absence of this contraceptive on the Ukrainian pharmaceutical market.

The greatest preference was gave by women of all age groups to a solid dosage form of non-hormonal contraceptives, namely suppositories. In the age groups from 16 to 34 years old, as well as in the $40-44$ year old group, spermicide in aerosol form was next in preference after contraceptive suppositories; although the value of the coefficients is 2 times lower than that of suppositories. This positive effect is explained, first, by the very low price (33 UAH or 0.95 EUR). Only in the age groups 35-39 years old and 45-49 years old, the second most preferred by women was a mild dosage form of spermicides, namely ointment.

Table 3 presents the $\beta$ utility coefficients of the attribute levels of contraceptive medical devices that were included in the third scenario of the RCA study.

The most preferred medical contraceptive device for women of all age groups was the male condom. The $\beta$ utility coefficients were in the range from 7.89 to $2.13-$

Table 1. $\beta$ utility coefficients of the levels of the hormonal contraceptive attribute.

\begin{tabular}{|c|c|c|c|c|c|c|c|c|c|c|c|c|c|c|}
\hline $\begin{array}{c}\text { Attribute levels of } \\
\text { hormonal contraceptives }\end{array}$ & $\begin{array}{c}16-19 \\
\text { years old }\end{array}$ & $\begin{array}{c}\text { standard } \\
\text { error }\end{array}$ & $\begin{array}{c}20-24 \\
\text { years old }\end{array}$ & $\begin{array}{l}\text { standard } \\
\text { error }\end{array}$ & $\begin{array}{c}25-29 \\
\text { years old }\end{array}$ & $\begin{array}{l}\text { standard } \\
\text { error }\end{array}$ & $\begin{array}{c}30-34 \\
\text { years old }\end{array}$ & $\begin{array}{c}\text { standard } \\
\text { error }\end{array}$ & $\begin{array}{c}35-39 \\
\text { years old }\end{array}$ & $\begin{array}{c}\text { standard } \\
\text { error }\end{array}$ & $\begin{array}{c}40-44 \\
\text { years old }\end{array}$ & $\begin{array}{l}\text { standard } \\
\text { error }\end{array}$ & $\begin{array}{c}45-49 \\
\text { years old }\end{array}$ & $\begin{array}{c}\text { standard } \\
\text { error }\end{array}$ \\
\hline Pills & -3.28 & .62 & 4.11 & .44 & 3.89 & .50 & 1.86 & .47 & 4.61 & .45 & 3.02 & .42 & -2.10 & .33 \\
\hline Injections & -.60 & .62 & 1.71 & .44 & .72 & .50 & 2.52 & .47 & 2.49 & .45 & 2.45 & .42 & -.51 & .33 \\
\hline Subcutaneous implant & 1.32 & .62 & -1.76 & .44 & -3.81 & .50 & -5.34 & .47 & -5.99 & .45 & -5.64 & .42 & -1.39 & .33 \\
\hline Skin patch & 4.24 & .62 & -.74 & .44 & .90 & .50 & 2.15 & .47 & 1.98 & .45 & .95 & .42 & 2.91 & .33 \\
\hline Vaginal ring & -4.25 & .62 & -.49 & .44 & -.01 & .50 & 1.02 & .47 & -1.16 & .45 & 1.77 & .42 & 2.23 & .33 \\
\hline $\begin{array}{l}\text { Intrauterine therapeutic } \\
\text { system }\end{array}$ & 2.57 & .62 & -2.82 & .44 & -1.68 & .50 & -2.22 & .47 & -1.92 & .45 & -2.56 & .42 & -1.14 & .33 \\
\hline Pearson's R & \multicolumn{2}{|c|}{.977} & \multicolumn{2}{|c|}{.990} & \multicolumn{2}{|c|}{.990} & \multicolumn{2}{|c|}{.985} & \multicolumn{2}{|c|}{.985} & \multicolumn{2}{|c|}{.987} & \multicolumn{2}{|c|}{.988} \\
\hline & \multicolumn{2}{|c|}{$\mathrm{p}<.005$} & \multicolumn{2}{|c|}{$\mathrm{p}<.005$} & \multicolumn{2}{|c|}{$\mathrm{p}<.005$} & \multicolumn{2}{|c|}{$\mathrm{p}<.005$} & \multicolumn{2}{|c|}{$\mathrm{p}<.005$} & \multicolumn{2}{|c|}{$\mathrm{p}<.005$} & \multicolumn{2}{|c|}{$\mathrm{p}<.005$} \\
\hline $\mathrm{R}^{2}$ & \multicolumn{2}{|c|}{0.955} & \multicolumn{2}{|c|}{0.980} & \multicolumn{2}{|c|}{0.980} & \multicolumn{2}{|c|}{0.970} & \multicolumn{2}{|c|}{0.970} & \multicolumn{2}{|c|}{0.974} & \multicolumn{2}{|c|}{0.976} \\
\hline \multirow[t]{2}{*}{ Kendall's $\tau$} & \multicolumn{2}{|c|}{.890} & \multicolumn{2}{|c|}{.921} & \multicolumn{2}{|c|}{.955} & \multicolumn{2}{|c|}{.942} & \multicolumn{2}{|c|}{.900} & \multicolumn{2}{|c|}{.926} & \multicolumn{2}{|c|}{.936} \\
\hline & \multicolumn{2}{|c|}{$\mathrm{p}<.005$} & \multicolumn{2}{|c|}{$\mathrm{p}<.005$} & \multicolumn{2}{|c|}{$\mathrm{p}<.005$} & \multicolumn{2}{|c|}{$\mathrm{p}<.005$} & \multicolumn{2}{|c|}{$\mathrm{p}<.005$} & \multicolumn{2}{|c|}{$\mathrm{p}<.005$} & \multicolumn{2}{|c|}{$\mathrm{p}<.005$} \\
\hline
\end{tabular}

Table 2. $\beta$ utility coefficients of the levels of the non-hormonal contraceptive attribute levels.

\begin{tabular}{|c|c|c|c|c|c|c|c|c|c|c|c|c|c|c|}
\hline $\begin{array}{c}\text { Attribute levels of non- } \\
\text { hormonal contraceptives }\end{array}$ & $\begin{array}{c}16-19 \\
\text { years old }\end{array}$ & $\begin{array}{l}\text { standard } \\
\text { error }\end{array}$ & $\begin{array}{c}20-24 \text { r } \\
\text { years old }\end{array}$ & $\begin{array}{c}\text { standard } \\
\text { error }\end{array}$ & $\begin{array}{c}25-29 \\
\text { years old }\end{array}$ & $\begin{array}{c}\text { standard } \\
\text { error }\end{array}$ & $\begin{array}{c}\text { 30-34 } \\
\text { years old }\end{array}$ & $\begin{array}{l}\text { standard } \\
\text { error }\end{array}$ & $\begin{array}{c}35-39 \\
\text { years old }\end{array}$ & $\begin{array}{c}\text { standard } \\
\text { error }\end{array}$ & $\begin{array}{c}40-44 \\
\text { years old }\end{array}$ & $\begin{array}{c}\text { standard } \\
\text { error }\end{array}$ & $\begin{array}{c}45-49 \\
\text { years old }\end{array}$ & $\begin{array}{c}\text { standard } \\
\text { error }\end{array}$ \\
\hline Vaginal suppositories & 3.81 & .33 & 2.41 & .17 & 3.77 & .14 & 2.50 & .34 & 2.87 & .32 & 1.40 & .20 & -.03 & .17 \\
\hline Vaginal cream/ointment & .42 & .33 & .07 & .17 & .01 & .14 & .79 & .34 & .18 & .32 & .42 & .20 & 1.59 & .17 \\
\hline Vaginal aerosol & .48 & .33 & .34 & .17 & .74 & .14 & 1.10 & .34 & -1.04 & .32 & 1.35 & .20 & 1.41 & .17 \\
\hline Sponge with contraceptive & -4.72 & .33 & -2.83 & .17 & -4.52 & .14 & -4.40 & .34 & -2.01 & .32 & -3.18 & .20 & -2.96 & .17 \\
\hline \multirow[t]{2}{*}{ Pearson's R } & \multicolumn{2}{|c|}{.988} & \multicolumn{2}{|c|}{.996} & \multicolumn{2}{|c|}{.997} & \multicolumn{2}{|c|}{.985} & \multicolumn{2}{|c|}{.985} & \multicolumn{2}{|c|}{.994} & \multicolumn{2}{|c|}{.996} \\
\hline & \multicolumn{2}{|c|}{$\mathrm{p}<.005$} & \multicolumn{2}{|c|}{$\mathrm{p}<.005$} & \multicolumn{2}{|c|}{$\mathrm{p}<.005$} & \multicolumn{2}{|c|}{$\mathrm{p}<.005$} & \multicolumn{2}{|c|}{$\mathrm{p}<.005$} & \multicolumn{2}{|c|}{$\mathrm{p}<.005$} & \multicolumn{2}{|c|}{$\mathrm{p}<.005$} \\
\hline $\mathrm{R}^{2}$ & \multicolumn{2}{|c|}{0.976} & \multicolumn{2}{|c|}{0.992} & \multicolumn{2}{|c|}{0.994} & \multicolumn{2}{|c|}{0.970} & \multicolumn{2}{|c|}{0.970} & \multicolumn{2}{|c|}{0.988} & \multicolumn{2}{|c|}{0.992} \\
\hline \multirow[t]{2}{*}{ Kendall's $\tau$} & \multicolumn{2}{|c|}{.928} & \multicolumn{2}{|c|}{.942} & \multicolumn{2}{|c|}{.971} & \multicolumn{2}{|c|}{.891} & \multicolumn{2}{|c|}{.928} & \multicolumn{2}{|c|}{.942} & \multicolumn{2}{|c|}{.962} \\
\hline & \multicolumn{2}{|c|}{$\mathrm{p}<.005$} & \multicolumn{2}{|c|}{$\mathrm{p}<.005$} & \multicolumn{2}{|c|}{$\mathrm{p}<.005$} & \multicolumn{2}{|c|}{$\mathrm{p}<.005$} & \multicolumn{2}{|c|}{$\mathrm{p}<.005$} & \multicolumn{2}{|c|}{$\mathrm{p}<.005$} & \multicolumn{2}{|c|}{$\mathrm{p}<.005$} \\
\hline
\end{tabular}


the highest value for the group indicator. The affordability, as well as the significant depth of the assortment on the pharmaceutical market of Ukraine (Mahanova and Tkachenko 2019b) explain this result. After the male condom the next in preference for women was the IUC copper/ gold/silver. Only in the age group 35-39 years the value of the coefficient for the spiral was lower than other coefficients, $\beta<0$. The least preferred contraceptive medical device among all age groups were the diaphragm and cervical cap. Their values of $\beta$ coefficients range from -4.64 to 0.19 were the smallest indicators for the groups. Low values of these coefficients are explained by the lack of these medical devices in pharmacies in Ukraine, as well as by the low awareness of women about the existence of such types of contraceptives.

An intermediate result of the coefficient values was obtained for female condoms, occupying the $3^{\text {rd }}$ position in terms of intragroup preferences, only in two age categories $20-24$ and $45-49$ years, $\beta>0$.

The considered utility coefficients of the price attribute levels, in all age groups, confirmed the main economic law of Alfred Marshall: the utility (attractiveness) of the price in its essence is the sensitivity (elasticity) to the price. The relationship is linear. Thus, the highest price $-100 \%$ of the maximum market value - turned out to be the most unattractive, and the value of $\beta$ coefficients was maximum at $0 \%$ payment from the market value of the contraceptive (Fig. 1).

Considering the resulting graphs, we can introduce the concept of price elasticity of preferences, by analogy with the concept of price elasticity of demand, since the curves for different contraceptives (hormonal, non-hormonal, medical device) are located at different angles to the $\mathrm{X}$-axis. The assumption of the existence of such a dependence makes it possible to predict changes in consumer preferences when prices change.

In addition, we examined the utility coverage (relative importance) of the price and contraceptive attributes in each of the age groups for each hypothetical study scenario. Attribute significance shows how important each attribute is in making a purchasing decision, the "contribution" of an attribute to a decision when choosing a contraceptive.

It was found that the significance of the price attribute is slightly higher in the second scenario in all age groups. When a woman made a hypothetical purchase of non-hormonal contraceptive drugs, she primarily focused on the cost of the drug, and then on the dosage form and the utility (benefits) of the contraceptive itself. Among the age groups, it is necessary to distinguish two groups at the

Table 3. $\beta$ utility coefficients of the attribute levels of contraceptive medical devices.

\begin{tabular}{|c|c|c|c|c|c|c|c|c|c|c|c|c|c|c|}
\hline $\begin{array}{l}\text { Attribute levels of medical } \\
\text { contraceptive devices }\end{array}$ & $\begin{array}{c}16-19 \\
\text { years old }\end{array}$ & $\begin{array}{c}\text { standard } \\
\text { error }\end{array}$ & $\begin{array}{c}20-24 \text { r } \\
\text { years old }\end{array}$ & $\begin{array}{c}\text { standard } \\
\text { error }\end{array}$ & $\begin{array}{c}25-29 \\
\text { years old }\end{array}$ & $\begin{array}{c}\text { standard } \\
\text { error }\end{array}$ & $\begin{array}{c}30-34 \\
\text { years old }\end{array}$ & $\begin{array}{l}\text { standard } \\
\text { error }\end{array}$ & $\begin{array}{c}35-39 \\
\text { years old }\end{array}$ & $\begin{array}{c}\text { standard } \\
\text { error }\end{array}$ & $\begin{array}{c}40-44 \\
\text { years old }\end{array}$ & $\begin{array}{c}\text { standard } \\
\text { error }\end{array}$ & $\begin{array}{c}45-49 \\
\text { years old }\end{array}$ & $\begin{array}{c}\text { standard } \\
\text { error }\end{array}$ \\
\hline IUC & 1.60 & .35 & 2.69 & .25 & .65 & .16 & 2.27 & .30 & -.54 & .29 & 1.44 & .30 & .80 & .24 \\
\hline Female condoms & 7.89 & .35 & 4.35 & .25 & 6.03 & .16 & 5.04 & .30 & 4.55 & .29 & 4.45 & .30 & 2.13 & .24 \\
\hline Male condoms & -.66 & .35 & .15 & .25 & -.53 & .16 & -1.12 & .30 & -.04 & .29 & -.48 & .30 & .42 & .24 \\
\hline Cervical cap & -4.64 & .35 & -3.36 & .25 & -2.06 & .16 & -1.99 & .30 & -2.57 & .29 & -3.52 & .30 & .19 & .24 \\
\hline Diaphragm & -4.18 & .35 & -3.83 & .25 & -4.08 & .16 & -4.20 &, 30 & -1.39 & .29 & -1.88 & .30 & -3.55 & .24 \\
\hline Pearson's R & \multicolumn{2}{|c|}{.990} & \multicolumn{2}{|c|}{.995} & \multicolumn{2}{|c|}{.997} & \multicolumn{2}{|c|}{.991} & \multicolumn{2}{|c|}{.990} & \multicolumn{2}{|c|}{.991} & \multicolumn{2}{|c|}{.995} \\
\hline & \multicolumn{2}{|c|}{$\mathrm{p}<.005$} & \multicolumn{2}{|c|}{$\mathrm{p}<.005$} & \multicolumn{2}{|c|}{$\mathrm{p}<.005$} & \multicolumn{2}{|c|}{$\mathrm{p}<.005$} & \multicolumn{2}{|c|}{$\mathrm{p}<.005$} & \multicolumn{2}{|c|}{$\mathrm{p}<.005$} & \multicolumn{2}{|c|}{$\mathrm{p}<.005$} \\
\hline $\mathrm{R}^{2}$ & \multicolumn{2}{|c|}{0.980} & \multicolumn{2}{|c|}{0.990} & \multicolumn{2}{|c|}{0.994} & \multicolumn{2}{|c|}{0.982} & \multicolumn{2}{|c|}{0.980} & \multicolumn{2}{|c|}{0.982} & \multicolumn{2}{|c|}{0.990} \\
\hline \multirow[t]{2}{*}{ Kendall's $\tau$} & \multirow{2}{*}{\multicolumn{2}{|c|}{$\begin{array}{c}.921 \\
p<.005\end{array}$}} & \multicolumn{2}{|c|}{.945} & \multicolumn{2}{|c|}{.971} & \multicolumn{2}{|c|}{.959} & \multicolumn{2}{|c|}{.936} & \multicolumn{2}{|c|}{.939} & \multicolumn{2}{|c|}{.936} \\
\hline & & & \multicolumn{2}{|c|}{$\mathrm{p}<.005$} & \multicolumn{2}{|c|}{$\mathrm{p}<.005$} & \multicolumn{2}{|c|}{$\mathrm{p}<.005$} & \multicolumn{2}{|c|}{$\mathrm{p}<.005$} & \multicolumn{2}{|c|}{$\mathrm{p}<.005$} & \multicolumn{2}{|c|}{$\mathrm{p}<.005$} \\
\hline
\end{tabular}

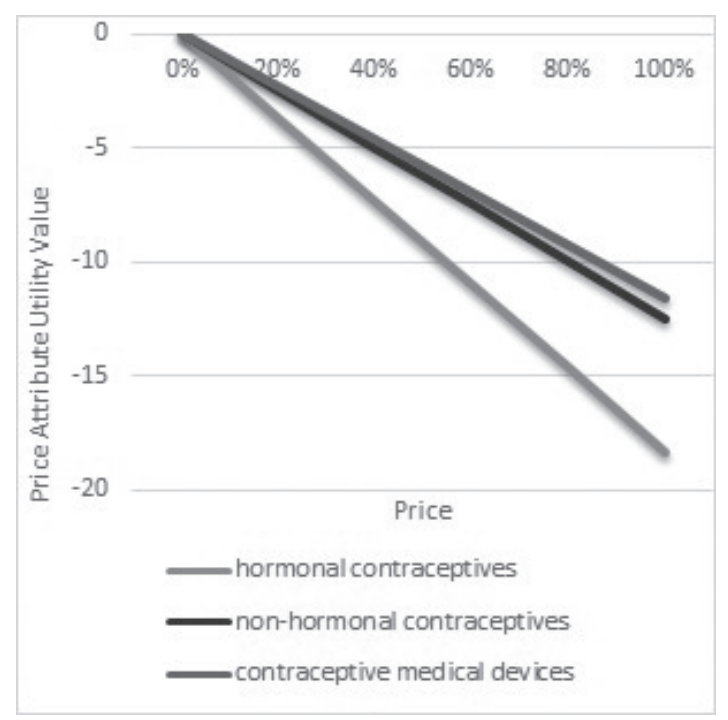

A) group of women 16-19 years old.

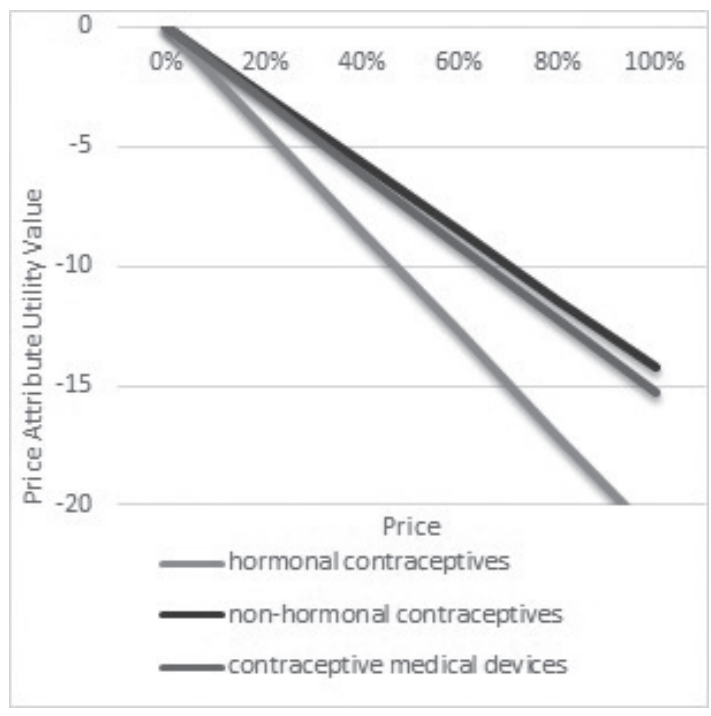

B) group of women 20-24 years old.

Figure 1. Price elasticity of preferences in different age groups. 


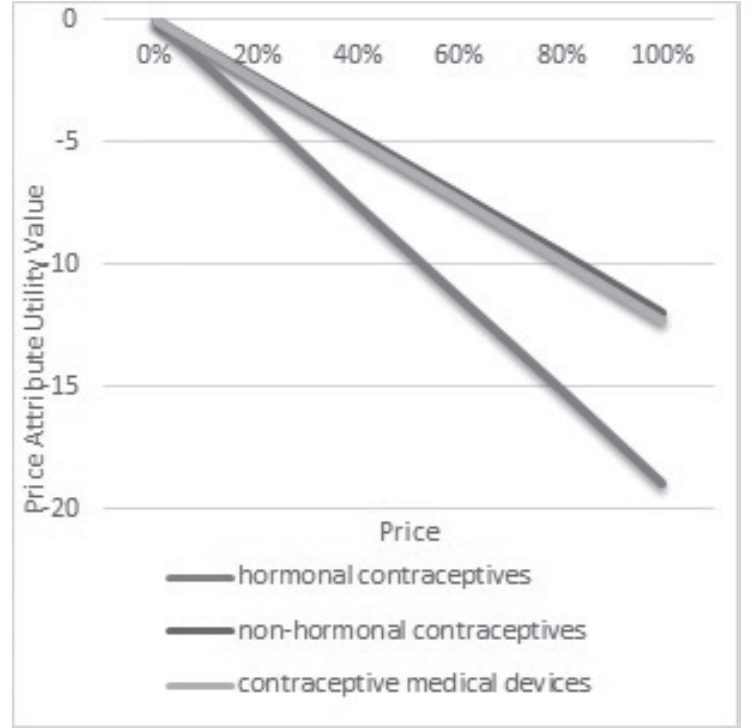

C) group of women $25-29$ years old.

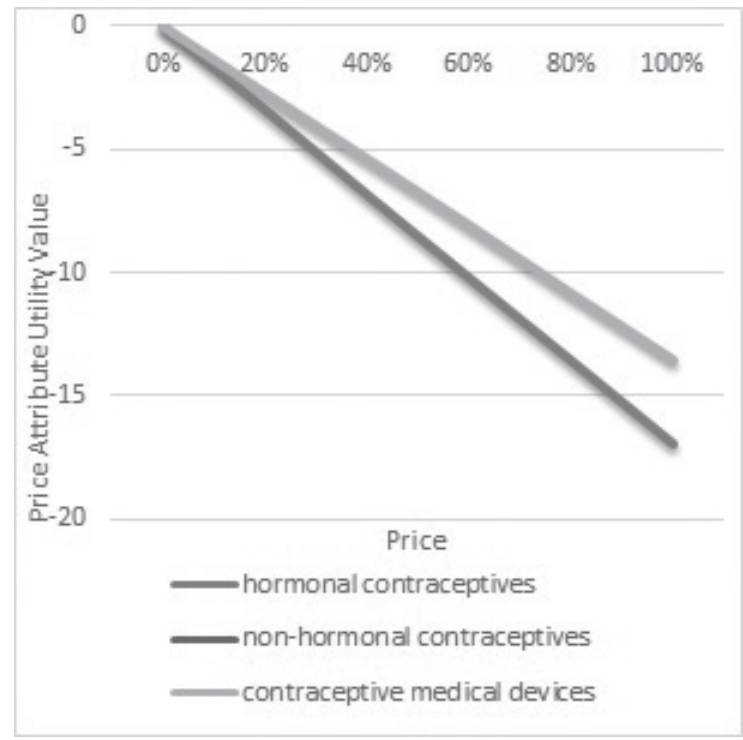

E) group of women $35-39$ years old.

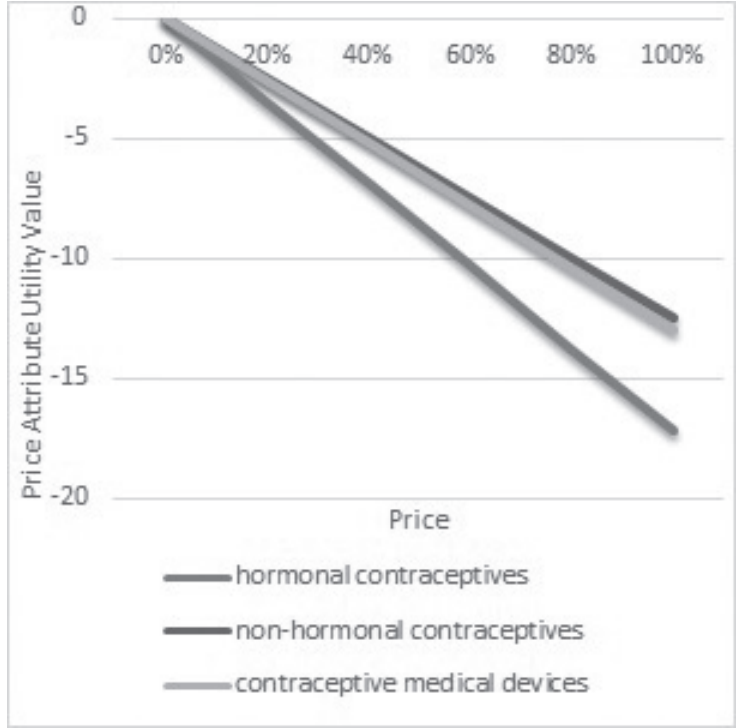

D) group of women 30-34 years old.

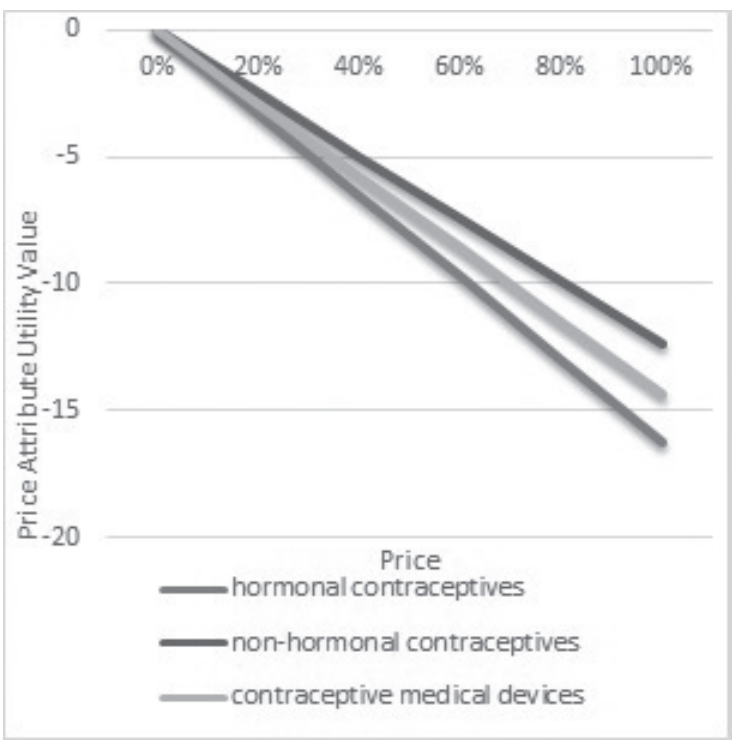

F) group of women $40-44$ years old.

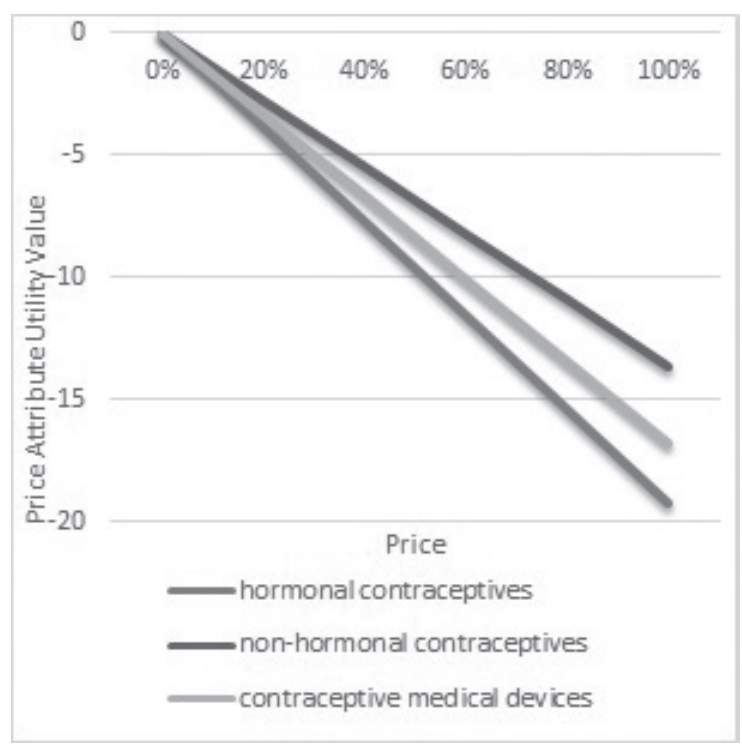

Figure 1. Continued.

G) group of women 45-49 years old. 
Table 4. The utility coverage of the price and contraceptive attributes in the age groups.

\begin{tabular}{|c|c|c|c|c|c|c|}
\hline & \multicolumn{2}{|c|}{ Scenario 1} & \multicolumn{2}{|l|}{ Scenario 2} & \multicolumn{2}{|l|}{ Scenario 3} \\
\hline & \multicolumn{6}{|c|}{ Utility coverage (relative importance) } \\
\hline & Hormonal contraceptives & Price & Non-hormonal contraceptives & Price & Contraceptive medical devices & Price \\
\hline $16-19$ years old & $50.85 \%$ & $49.14 \%$ & $47.36 \%$ & $52.63 \%$ & $62.38 \%$ & $37.61 \%$ \\
\hline $20-24$ years old & $41.38 \%$ & $58.61 \%$ & $38.07 \%$ & $61.93 \%$ & $47.80 \%$ & $52.19 \%$ \\
\hline $25-29$ years old & $48.31 \%$ & $51.69 \%$ & $49.54 \%$ & $50.45 \%$ & $58.82 \%$ & $41.17 \%$ \\
\hline $30-34$ years old & $53.69 \%$ & $46.30 \%$ & $47.32 \%$ & $52.67 \%$ & $57.19 \%$ & $42.81 \%$ \\
\hline $35-39$ years old & $55.23 \%$ & $44.76 \%$ & $45.58 \%$ & $54.41 \%$ & $54.89 \%$ & $45.10 \%$ \\
\hline $40-44$ years old & $57.41 \%$ & $42.58 \%$ & $48.24 \%$ & $51.75 \%$ & $53.49 \%$ & $46.50 \%$ \\
\hline $45-49$ years old & $49.20 \%$ & $50.79 \%$ & $44.70 \%$ & $55.29 \%$ & $46.60 \%$ & $53.39 \%$ \\
\hline
\end{tabular}

age from 20 to 24 years old and from 45 to 49 years old, which in all scenarios of the experiment were primarily guided by the price, and only after by the characteristics of the contraceptive. The same situation is observed for the first scenario in the age group from 25 to 29 years old (Table 4).

The results obtained make it possible to predict a woman's reaction to the choice of a contraceptive when the price changes, that is, in groups where the "contribution" of the price attribute to the decision to choose is greater than the "contribution" of other attributes, it is possible to talk about a change in women's preferences among contraceptives when the price changes and vice versa.

\section{Conclusion}

Based on the results of the studies, it is possible to draw such conclusions about the preferences of contraceptives among Ukrainian women of reproductive age.

It was found that in the group of women aged 16-19, respondents gave preference to a skin patch, an intrauterine therapeutic system and a subcutaneous implant, which indicates the adherence of young women to more convenient and long-term using methods of hormonal contraceptives. Women aged 20-24 and 25-29 chose the tablet and injectable form of hormonal contraceptives.

In the age groups of 30-34 and 40-44 years, approximately the same preferences were gave by women to injectable, cutaneous and oral forms of hormonal contraceptives $(\beta=2.52 ; 2.15 ; 1.86)$. Women aged $35-39$ chose pill, injectable and cutaneous forms of hormonal contraceptives. For women aged 45-49 years, the only attractive contraceptive methods were patch and vaginal ring. Thus, in most age groups, hormonal pills were in first place in terms of preferences. It is primarily due to the active prescription of these drugs by doctors, as well as the depth of the range of drugs on the pharmaceutical market of Ukraine.

Among non-hormonal contraceptives, women of all age groups gave the greatest preference to a solid dosage form, namely suppositories. Contraceptive aerosol, due to its price, and contraceptive ointment shared the second place in preference.

The most preferred medical contraceptive device for women of all age groups was the male condom. The affordability, as well as the significant depth of the assortment of the Ukrainian pharmaceutical market explain this result. After the male condom, the next in preference for women was IUC with copper/gold/silver.

The lowest preference among contraceptive in all age groups was gave to a subcutaneous implant, an intrauterine therapeutic system, a sponge with spermicide, a diaphragm, and a cervical cap. Such a consumer's reaction to the product is primarily associated with the lack of sufficient information among the majority of women about these contraceptives, and associated with the absence of these contraceptives in drug stores and the significant price for them.

The main economic law of Alfred Marshall was confirmed: the utility (attractiveness) of the price in its essence is the sensitivity (elasticity) to the price. The relationship is linear.

Established the utility coverage of attributes in the selection of contraceptives. Thus, in the second hypothetical scenario for studying the preferences of non-hormonal contraceptives, the significance of the price attribute was slightly higher than the significance of the attribute of the contraceptives itself. When a woman made a hypothetical purchase of non-hormonal contraceptive drugs, she primarily focuses on the cost of the contraceptive. A similar result was observed in two groups aged 20 to 24 years and from 45 to 49 years, which in all scenarios of the experiment, first of all, were guided by the price, and then by the characteristics of the contraceptives. Such values indicate the adherence of women to a particular contraceptive, primarily in terms of price, and any jumps in cost are reflected not only in the choice of contraceptive, but also in the long term on the effectiveness of their use.

The obtained results on women's commitment to certain types of contraceptives will allow to increase the level of compliance and pharmaceutical safety of contraceptives, moreover information on the utility of contraceptives attributes will help to make the right price decisions in the contraception supply system, thereby promoting a balance between the needs of women and the capabilities of the system.

\section{Acknowledgements}

This research did not receive any specific grant from funding agencies in the public, commercial, or not-forprofit sectors. 


\section{References}

Ali MM, John C (2018) Long term trends in behavior to protect against adverse reproductive and sexual health outcomes among young single African women. Reproductive Health 15(1): e136. https://doi. org/10.1186/s12978-018-0576-6

Alsaleem MA, Khalil SN, Siddiqui AF, Alzahrani MM, Alsaleem SA (2018) Contraceptive use as limiters and spacers among women of reproductive age in southwestern, Saudi Arabia. Saudi Medical Journal 39(11): 109-1115. https://doi.org/10.15537/smj.2018.11.22817

Arroyo R, Sempere AP, Ruiz-Beato E, Prefasi D, Carreño A, Roset M, Maurino J (2017) Conjoint analysis to understand preferences of patients with multiple sclerosis for disease-modifying therapy attributes in Spain: a cross-sectional observational study. BMJ Open 7(3): e014433. https://doi.org/10.1136/bmjopen-2016-014433

Bridges JF, Hauber AB, Marshall D, Lloyd A, Prosser LA, Regier DA, Johnson FR, Mauskopf J (2011) Conjoint analysis applications in health-a checklist: a report of the ISPOR Good Research Practices for Conjoint Analysis Task Force. Value Health 14(4): 403-413. https:// doi.org/10.1016/j.jval.2010.11.013

Bugaevskyi KA (2016) Study of the peculiarities of contraceptive choice and reproductive behavior of female students of a medical university. Actual problems of modern medicine 4(56): 81-85. [In Ukrainian]

Cambridge Dictionary (2021) Meaning of hall test in English. https:// dictionary.cambridge.org/dictionary/english/hall-test

Chin-Quee DS, Stanback J, Orr T (2018) Family planning provision in pharmacies and drug shops: an urgent prescription. Contraception 98 (5): 379-382. https://doi.org/10.1016/j.contraception.2018.08.013

Criminal Code of Ukraine (2001) Criminal Code of Ukraine. https:// zakon2.rada.gov.ua/laws/show/2341-14

Debashis Parti (2002) Marketing research. Universities press, India, $676 \mathrm{pp}$.

Dobrenkov VI, Kravchenko AI (2007) Fundamental Sociology. Empirical and Applied Sociology. Publishing Center "Academy", Moscow, 392 pp. [In Russian]

Gormley R, Vickers B, Norman WV (2019) Comparing options for women seeking permanent contraception in high-resource countries: a protocol for a systematic review. Systematic Reviews 8: e74. https://doi.org/10.1186/s13643-019-0987-7

Hauber AB, González JM, Groothuis-Oudshoorn CG, Prior T, Marshall DA, Cunningham C, Ijzerman MJ, Bridges JF (2016) Statistical Methods for the Analysis of Discrete Choice Experiments: A Report of the ISPOR Conjoint Analysis Good Research Practices Task Force. Value Health 19(4): 300-315. https://doi.org/10.1016/j.jval.2016.04.004

Higgins JA, Ryder K, Skarda G, Koepsel E, Bennett EA (2015) The Sexual Acceptability of Intrauterine Contraception: A Qualitative Study of Young Adult Women. Perspect Sex Reprod Health 47(3): 115-122. https://doi.org/10.1363/47e4515

Jakimiuk AJ, Crosignani PG, Chernev T, Prilepskaya V (2011) High levels of women's satisfaction and compliance with transdermal contraception: results from a European multinational, 6-month study. Gynecological Endocrinology 27(10): 849-856. https://doi.org/10.3 109/09513590.2010.538095

Janevic T, Sarah PW, Leyla I, Elizabeth BH (2012) Individual and community level socioeconomic inequalities in contraceptive use in 10 Newly Independent States: a multilevel cross-sectional analysis. International Journal for Equity in Health 11: e69. https://doi. org/10.1186/1475-9276-11-69
Keith RJ (1986) The Marketing Revolution. Journal of Marketing 24(1): 35-38. https://doi.org/10.1177/002224296002400306

Kumar N, Scheer LK, Steenkamp JBEM (1995) The effects of perceived interdependence on dealer attitudes. Journal of Marketing Research 32: 348-356. https://doi.org/10.1177/002224379503200309

Mahanova TV, Tkachenko NO (2020a) Analysis of contraceptive drugs market in the context of pharmaceutical safety. Relevant nutrition of pharmaceutical and medical science and practice 1(32): 128-136. https://doi.org/10.14739/2409-2932.2020.1.198187 [In Ukrainian]

Mahanova TV, Tkachenko NO (2020b) The Analysis of the Ukrainian market of contraceptive medical devices in the context of pharmaceutical safety. Recipe 23(2-3): 223-234. https://doi.org/10.34883/ PI.2020.2.2.030 [In Ukrainian]

Mavranezouli I (2009) Health economics of contraception. Best Practice \& Research Clinical Obstetrics \& Gynaecology 23(2): 187-198. https://doi.org/10.1016/j.bpobgyn.2008.11.007

McCool-Myers M (2019) Implementing condom distribution programs in the United States: Qualitative insights from program planners. Evaluation and Program Planning 74: 20-26. https://doi. org/10.1016/j.evalprogplan.2019.02.006

Myagkov AYu (1996) Age as a variable in sociological research (methodological and methodological problems of measurement). TGU Bulletin 2: 31-38. https://cyberleninka.ru/article/n/vozrast-kak-peremennaya-v-sotsiologicheskom-issledovanii-metodologicheskie-i-metodicheskie-problemy-izmereniya/viewer [In Russian]

Norman WV, Burk JC (2019) Trends and determinants of postabortion contraception use in a Canadian retrospective cohort. Contraception 100(2): 96-100. https://doi.org/10.1016/j.contraception.2019.04.013

Order of the Ministry of Health of Ukraine (2014) About the statement and introduction of medical and technological documents on standardization of medical care concerning family planning 21.01.2014 № 59. https://zakon.rada.gov.ua/rada/show/v0059282-14\#Text [In Ukrainian]

Orme B (2007) Three Ways to Treat Overall Price in Conjoint Analysis, Sawtooth Software Inc., $11 \mathrm{pp}$.

Osipov GV (2009) Sociologist's workbook. $5^{\text {th }}$ edn. Book House “LIBROKOM", Moscow, 480 pp. [In Russian]

Rachok A, Pyshchulina O, Mishchenko M, Shangina L, Bichenko A (2016) The middle class in Ukraine. Imagination and reality, Razumkov Center, Kiev. https://www.google.com/url?sa=t\&rct=j\&q=\&es$\mathrm{rc}=\mathrm{s} \&$ source $=$ web \&cd $=$ \&ved $=2 \mathrm{ahUKEwiUkOvPr}-$ LtAhWpCRAI HX2mCTgQFjACegQIARAC\&url=https\%3A\%2F\%2Frazumkov. org.ua\%2Fuploads\%2Farticle\%2F2016_Seredn_klas.pdf\&usg=AOvVaw21VWxAGzS0HfrIb1IejeRc [In Ukrainian]

Snopkowski K, Towner MC, Shenk MK, Colleran H (2016) Pathways from education to fertility decline: a multi-site comparative study. Philosophical Transactions of the Royal Society B - Biological Sciences 19: e20150156. https://doi.org/10.1098/rstb.2015.0156

SPSS Inc. (1993-2007) SPSS Conjoint 17.0. Chicago, 63 pp. https:// $w w w . g o o g l e . c o m / u r l$ ? $s a=t \& r c t=j \& q=\& e s r c=s \&$ source $=w e b \& c-$ $\mathrm{d}=$ \&ved=2ahUKEwjP5djNsOLtAhVHpYsKHd8yDysQFjAAegQIAhAC\&url=http\%3A\%2F\%2Fwww.sussex.ac.uk\%2Fits\%2Fpdfs\%2FSPSS_Conjoint_17.0.pdf\&usg=AOvVaw2LEXTT6PVxg58bnpfcuRyJ State Statistics Service of Ukraine (2021) State Statistics Service of Ukraine. http://www.ukrstat.gov.ua/ 
Wright SJ, Ulph F, Lavender T, Dharni N, Payne K (2018) Understanding Midwives' Preferences for Providing Information About Newborn Bloodspot Screening. MDM Policy \& Practice 3(1): 1-13. https://doi. org/10.1177/2381468317746170

U-report (2011) U-report: poll. https://ukraine.ureport.in/v2/opinion/652/

Visser LA, Louapre C, Uyl-de Groot CA, Redekop WK (2020) Patient needs and preferences in relapsing-remitting multiple sclerosis: A systematic review. Mult Scler Relat Disord 2(39): e101929. https:// doi.org/10.1016/j.msard.2020.101929
World Health Organization (2015) Medical Eligibility Criteria For Contracetive Use. $5^{\text {th }}$ edn. Switzerland. https://www.who.int/publications/i/item/9789241549158

World Health Organization (2018) Woman and health. https://www. who.int/ru/news-room/fact-sheets/detail/women-s-health

Zaliska O, Stasiv K, Maksymovych N, Hrynkiv Y (2020) The trends of assisted reproductive technologies and cost for ovarian stimulation protocols in Ukraine. Pharmacia 67(4): 269-276. https://doi. org/10.3897/pharmacia.67.e55159 